\title{
Pertumbuhan dan Produksi Tiga Varietas Unggul Padi di Lahan Rawa Lebak Desa Jambu Ilir Kabupaten Ogan Komering Ilir, Sumatera Selatan
}

\author{
The Growth and Production Three Rice Superior Varieties in Swampy Lands at the Jambu \\ Ilir Village, Ogan Komering Ilir District South Sumatra \\ Suparwoto Suparwoto ${ }^{1 *}$ \\ ${ }^{1}$ Balai Pengkajian Teknologi Pertanian Sumatera Selatan, Sumatera Selatan 30151 \\ ${ }^{*}$ Penulis untuk korespondensi: suparwoto11@gmail.com
}

\begin{abstract}
The assessment was carried out in Jambu Ilir Village, Tanjung Lubuk District, Ogan Komering Ilir Regency, South Sumatra, starting from March until August 2018. Varieties exhibited were 2 superior varieties and 1 comparative variety, Mekongga. The aim of the study was to obtain information on the growth and production of Inpari 30 and Inpara 8 varieties that were adaptive and had high production on lebak lands. The study was designed by observation method, spacing of legowo 2 : $1(50 \times 25 \times 12.5 \mathrm{~cm})$, seedling age 35 days after seedling, 2-3 seeds / holes. The dosage of fertilizer used is $150 \mathrm{~kg}$ Urea, $100 \mathrm{~kg} \mathrm{SP}-36$ and $100 \mathrm{~kg} \mathrm{KCl} / \mathrm{ha}$. The variables observed were: plant height, number of productive tillers, number of grain per panicle, number of filled grains per panicle, and grain yield per ha. The data obtained was arranged in tabulation and analyzed by statistical tests, namely the test of the mean value (test-t). The results showed that the plant height of the varieties exhibited was classified as low to moderate with the number of productive tillers classified as moderate. Inpari 30, and Inpara 8 can adapt well in lebak lands with a production of 5.1-5.3 tons dry grain harvestDGH/ha higher than Mekongga as a comparison variety and are highly favored by farmers.
\end{abstract}

Keywords: growth and production, rice varieties, swampy lands

\begin{abstract}
ABSTRAK
Pengkajian dilaksanakan di Desa Jambu Ilir, Kecamatan Tanjung Lubuk, Kabupaten Ogan Komering Ilir, Sumatera Selatan, dimulai dari Maret sampai dengan Agustus 2018. Varietas yang diperagakan 2 VUB dan 1 varietas pembanding yaitu Mekongga. Tujuan pengkajian untuk mendapatkan informasi pertumbuhan dan produksi varietas Inpari 30 dan Inpara 8 yang adaptif dan memiliki produksi tinggi di lahan rawa lebak. Pengkajian dirancang dengan metoda observasi, jarak tanam legowo 2:1 (50x25x12,5 cm), umur bibit 35 hari setelah semai, 2-3 bibit/lubang. Dosis Pupuk yang digunakan adalah $150 \mathrm{~kg}$ Urea, $100 \mathrm{~kg} \mathrm{SP}-36$ dan $100 \mathrm{~kg} \mathrm{KCl} / \mathrm{ha}$. Peubah yang diamati adalah: tinggi tanaman, jumlah anakan produktif, jumlah gabah per malai, jumlah gabah isi per malai, dan hasil gabah per ha. Data yang diperoleh disusun secara tabulasi dan dianalisis dengan uji statistik yaitu uji kesamaan nilai tengah (uji-t). Hasil menunjukkan bahwa tinggi tanaman dari varietas yang diperagakan tergolong rendah sampai sedang dengan jumlah anakan produktif tergolong sedang. Inpari 30, dan Inpara 8 dapat beradaptasi baik di rawa lebak dengan produksi 5,1-5,3 ton gabah kering panen (GKP)/ha lebih tinggi dari Mekongga sebagai varietas pembanding dan sangat disukai para petani.
\end{abstract}


Kata kunci: pertumbuhan dan produksi, varietas padi, rawa lebak

\section{PENDAHULUAN}

Potensi rawa lebak di Provinsi Sumatera Selatan belum banyak dimanfaatkan atau dikembangkan khususnya untuk tanaman pangan terutama padi. Hal ini disebabkan karena tinggi genangan air yang tidak menentu sehingga produktivitas padi di lahan rawa lebak masih rendah. Kabupaten Ogan Komering Ilir (OKI) merupakan salah satu sentra penghasil padi di Provinsi Sumatera Selatan. Menurut Badan Pusat Statistik (BPS) Provinsi Sumatera Selatan tahun 2016, lahan sawah di Kabupaten OKI seluas 185.998 ha, yang terdiri dari sawah irigasi seluas 650 hektar dan sawah non irigasi seluas 185.348 ha. Berdasarkan data BPS Tahun 2016, tingkat produktivitas padi di Kabupaten OKI, yaitu 4,619 ton/ha, lebih rendah dibandingkan produktivitas Provinsi Sumatera Selatan sebesar 4,998 ton/ha. Kecamatan Tanjung Lubuk merupakan salah satu dari 19 kecamatan di Kabupaten OKI yang terdiri dari 22 desa dengan luas wilayah $222,97 \mathrm{~km}^{2}$, salah satunya Desa Jambu Ilir. Luas lahan pertanian menurut penggunaannya yaitu tadah hujan 1.643 ha, dan lebak 10.260 ha. Kecamatan Tanjung Lubuk terletak pada ketinggian 6-10 meter dari permukaan laut, $\mathrm{pH}$ tanah 4-7 dengan kemiringan 0$15 \%$ dan kedalaman gambut $0,5-1$ meter, bulan basah selama 6 bulan yaitu antara Oktober - Maret dan bulan kering AprilSeptember. Curah hujan rata-rata $1500-$ $2500 \mathrm{~mm} /$ tahun dan suhu minimum ratarata $23-32^{\circ} \mathrm{C}$. Para petani di desa ini telah melaksanakan pertanaman padi satu tahun dua kali yaitu pada musim kemarau bulan April dan musim penghujan bulan Oktober (BP3K Tanjung Lubuk, 2014).

Masalah agronomis yang dihadapi petani pada lahan sawah lebak umumnya adalah: (1) penggunaan varietas lokal berdaya hasil rendah dan berumur panjang, (2) mutu benih rendah, (3) pemupukan tidak sesuai dosis anjuran dan tidak berimbang, (4) pengendalian gulma dan hama tidak optimal. Hama yang sering merusak tanaman padi ialah keong mas, walang sangit dan kepik. Kemudian Suryana (2016) mengatakan bahwa lahan rawa lebak mempunyai kendala di antaranya fluktuasi air yang cukup tinggi, yaitu banjir pada musim hujan dan kekeringan pada musim kemarau terutama pada lahan rawa lebak dangkal, prasarana pendukung belum memadai seperti jalan usahatani dan saluran drainase, terbatasnya modal usahatani. Varietas lokal yang biasa ditanam petani ialah Sepitik, Kuning dan varietas unggul Ciherang, Ciliwung dan Mekongga. Varietas Ciherang, Ciliwung dan Mekongga didapat dari petani Kecamatan Tugu Mulia dan Dinas ketahanan pangan dan TPH Kabupaten OKI. Dikemukakan oleh Idris (2008) dalam Helmi dan Sembiring, (2013) penggunaan varietas unggul yang ditanam terus menerus akan mengalami perubahan antara lain kemurnian varietas dan reaksinya terhadap hama dan penyakit tertentu semakin menurun. Menurut Soehendi dan Syahri (2013), penggunan varietas unggul masih terbatas pada varietas Ciherang dan beberapa varietas lokal seperti Pegagan, Siputih yang telah ditanam secara terus-menerus dengan produktivitas yang rendah 3 ton GKP/ha. Penggunaan varietas unggul yang sesuai dengan tempat tumbuhnya merupakan salah satu komponen teknologi yang dapat meningkatan produktivitas padi dan mudah diadopsi oleh petani karena murah dan mudah penggunaannya. Hasil penelitian sebelumnya oleh Mustikawati (2016) penggunaan varietas unggul Inpara 1, Inpara 2, Inpara 3, Inpara 4, Inpara 5 di lahan rawa lebak Lampung Selatan, hasil gabah yang diperoleh 4,49-5,80 ton GKP/ha dan Ciherang 4,5 ton GKP/ha. Keragaan varietas Inpari dan Inpara yang dikembangkan di lahan rawa lebak Kabupaten Banyuasin Sumatera Selatan dimana produksi gabah Inpara 4 dan Inpari 
22 berkisar 6,8 ton $\mathrm{GKP} /$ ha dan 7,0 ton GKP/ha, serta Inpari 30 dengan produksi 6,1 ton gkp/ha (Suparwoto et al, 2017). Penelitian ini bertujuan mendapatkan informasi pertumbuhan dan produksi varietas Inpari 30 dan Inpara 8 yang adaptif dan memiliki produksi tinggi di lahan rawa lebak.

\section{BAHAN DAN METODE}

Kegiatan dilaksanakan di Desa Jambu Ilir, Kecamatan Tanjung Lubuk, Kabupaten Ogan Komering Ilir, Sumatera Selatan pada musim kemarau 2018. Bahan yang dibutuhkan antara lain: benih padi, pupuk urea, SP-36, KCl, Insektisida, herbisida. Selain itu alat yang dibutuhkan antara lain: hand traktor, meteran, tali jarak tanam, timbangan, parang, cangkul, sprayer. Varietas unggul yang diperagakan adalah 3 varietas yaitu Inpari 30, Inpara 8, dan Mekongga seluas tiga hektar. Keunggulan Inpari 30 toleran rendaman pada fase vegetative selama 15 hari, sedangkan Inpara 8 toleran keracunan $\mathrm{Fe}$ dan dianjurkan untuk lebak dangkal dan lebak tengahan. Kedua varietas tersebut mempunyai tekstur nasi pulen. Pupuk yang digunakan $150 \mathrm{~kg}$ Urea, $100 \mathrm{~kg}$ SP-36 dan $100 \mathrm{~kg} \mathrm{KCl} / \mathrm{ha}$. Pemupukan dilakukan 2 kali yaitu pada umur 1 minggu setelah tanam (MST) dengan takaran $75 \mathrm{~kg}$ urea, $100 \mathrm{~kg} \mathrm{SP}-36$ dan $100 \mathrm{~kg} \mathrm{KCl} / \mathrm{ha}$ dan pada umur 4 minggu setelah tanam (MST) dengan takaran $75 \mathrm{~kg}$ urea/ha. Sistem tanam yang digunakan legowo $2: 1(50 \mathrm{~cm}$ x $25 \mathrm{~cm}$ $\mathrm{x} \quad 12,5 \mathrm{~cm})$. Data yang dikumpulkan meliputi: tinggi tanaman saat panen, jumlah anakan produktif/rumpun, jumlah gabah per malai, jumlah gabah isi per malai, dan produksi gabah konversi per hektar. Hasil gabah diambil dengan ubinan $(3 \times 4 \mathrm{~m})$. Setiap parameter diambil 10 sampel tanaman dan hasil gabah diambil tiga kali ubinan. Metoda yang digunakan adalah pengamatan langsung di lapangan (observasi) terhadap varietas unggul yang diperagakan. Data yang diperoleh disusun secara tabulasi dan dianalisis dengan uji statistik yaitu uji kesamaan nilai tengah (uji-t) dengan aplikasi SPSS 11.

\section{HASIL}

Berdasarkan hasil analisis statistik bahwa pertumbuhan dan produksi dari berbagai varietas yang ditampilkan berpengaruh nyata dan sangat nyata terhadap parameter yang diamati kecuali jumlah anakan produktif dan produksi disajikan pada Tabel 1, 2, 3, 4, 5 dan 6). Pada Tabel 1, menunjukkan bahwa tinggi tanaman dari Inpara 8, Inpari 30 dan Mekongga (kontrol) bervariasi rata-rata $102,2-114,6 \mathrm{~cm}$, dimana tinggi tanaman Inpara 8 berbeda sangat nyata dengan Mekongga dan berbeda nyata dengan Inpari 30, sedangkan Inpari 30 tidak berbeda nyata dengan Mekongga. Inpara 8 merupakan tanaman tertinggi dari varietas lainnya yaitu $114,6 \mathrm{~cm}$ dan terendah $102,2 \mathrm{~cm}$ varietas Mekongga.

Tabel 1. Keragaan tinggi tanaman $(\mathrm{cm})$ tiga varietas unggul di Desa Jambu ilir Kab.OKI, 2018

\begin{tabular}{lccc}
\hline Varietas & Rata-rata & Inpara 8 & Inpari 30 \\
\hline Inpara 8 & 114,6 & - & \\
Inpari 30 & 105,8 & $*$ & - \\
Mekongga & 102,2 & $* *$ & tn \\
\hline Rata-rata & 107,5 & & \\
\hline
\end{tabular}

Keterangan :

tn $=$ tidak berbeda nyata $($ Probabilitas $>0.05)$

$* *$ = berbeda sangat nyata (Probabilitas $<0.01$ )

$*$ = berbeda nyata (Probabilitas $<0.05$ ) 
Jumlah anakan produktif dari ke tiga varietas tersebut tidak menunjukkan perbedaan yang nyata, tetapi secara visual bahwa varietas Inpara 8 dan Inpari 30 mempunyai anakan produktif lebih banyak dari Mekongga berturut-turut 16,2 dan 16,8 batang/rumpun (Tabel 2). Parameter panjang malai dari ke tiga varietas tersebut secara statistik menunjukkan bahwa Inpara 8 berbeda sangat nyata dengan Mekongga dan berbeda nyata dengan Inpari 30, sedangkan Inpari 30 juga berbeda sangat nyata dengan Mekongga. Panjang malai dari Inpara 8 dan Inpari 30 lebih panjang dari Mekongga berturut turut 26,2 dan 24, 9 cm (Tabel 3).

Jumlah gabah/malai dari Inpara 8 lebih banyak dari Mekongga dan Inpari 30 yaitu 157,3 butir/malai, berbeda sangat nyata dengan Mekongga dan berbeda tidak nyata dengan Inpari 30. Jumlah gabah/malai terrendah dimiliki oleh Mekongga yaitu 108,3 butir/malai (Tabel 4).

Selanjutnya Inpara 8 juga memiliki jumlah gabah isi/malai terbanyak yaitu 140 , 3 butir/malai dibandingkan Inpari 30 dan Mekongga dan secara statistik berbeda sangat nyata dengan Mekongga dan berbeda tidak nyata dengan Inpari 30 sedangkan Inpari 30 berbeda nyata dengan Mekongga (Tabel 5).

Secara visual produksi gabah bervariasi dari 4,1-5,3 ton GKP/ha, dimana produksi Inpara 8 dan Inpari 30 lebih tinggi dari Mekongga (4,1 ton GKP/ha) (Tabel 6).

Tabel 2. Keragaan jumlah anakan produktif (btg) tiga varietas di Desa Jambu ilir Kab. OKI, 2018

\begin{tabular}{lccc}
\hline Varietas & Rata-rata & Inpara 8 & Inpari 30 \\
\hline Inpara 8 & 16,2 & - & \\
Inpari 30 & 16,8 & tn & - \\
Mekongga & 14,7 & tn & tn \\
\hline Rata-rata & 15,9 & & \\
\hline
\end{tabular}

Keterangan : $\operatorname{tn}=$ tidak berbeda nyata $($ Probabilitas $>0.05)$

Tabel 3. Keragaan panjang malai $(\mathrm{cm})$ tiga varietas unggul di Desa Jambu ilir Kab.OKI, 2018

\begin{tabular}{lccc}
\hline Varietas & Rata-rata & Inpara 8 & Inpari 30 \\
\hline Inpara 8 & 26,2 & - & \\
Inpari 30 & 24,9 & $*$ & - \\
Mekongga & 23,9 & $* *$ & $* *$ \\
\hline Rata-rata & 25,0 & & \\
\hline
\end{tabular}

Keterangan :

$* *$ = berbeda sangat nyata (Probabilitas $<0.01)$

$*$ = berbeda nyata (Probabilitas $<0.05)$

Tabel 4. Keragaan jumlah gabah/malai (butir) tiga varietas unggul di Desa Jambu ilir Kab. OKI, 2018

\begin{tabular}{lccc}
\hline Varietas & Rata-rata & Inpara 8 & Inpari 30 \\
\hline Inpara 8 & 157,3 & - & \\
Inpari 30 & 151,7 & tn & - \\
Mekongga & 108,3 & $* *$ & $*$ \\
\hline Rata-rata & 139,1 & & \\
\hline
\end{tabular}

Keterangan :

tn $=$ tidak berbeda nyata (Probabilitas $>0.05)$

$* *$ = berbeda sangat nyata (Probabilitas $<0.01$ )

$*$ = berbeda nyata (Probabilitas $<0.05$ ) 
Tabel 5. Keragaan jumlah gabah isi/malai (btr) tiga varietas unggul di Desa Jambu ilir Kab.OKI, 2018

\begin{tabular}{lccc}
\hline Varietas & Rata-rata & Inpara 8 & Inpari 30 \\
\hline Inpara 8 & 140,3 & - & \\
Inpari 30 & 126,6 & $* *$ & - \\
Mekongga & 95,6 & $* *$ & $* *$ \\
\hline Rata-rata & 120,8 & & \\
\hline
\end{tabular}

Keterangan :

$* *$ = berbeda sangat nyata (Probabilitas < 0.01)

Tabel 6. Keragaan produksi gabah (GKP/ha) tiga varietas unggul di Desa Jambu ilir Kab.OKI, 2018

\begin{tabular}{lccc}
\hline Varietas & Rata-rata & Inpara 8 & Inpari 30 \\
\hline Inpara 8 & 5,3 & - & \\
Inpari 30 & 5,1 & tn & - \\
Mekongga & 4,1 & tn & tn \\
\hline Rata-rata & 4,8 & & \\
\hline
\end{tabular}

Keterangan :

tn $=$ tidak berbeda nyata $($ Probabilitas $>0.05)$

\section{Preferensi Petani}

Preferensi petani diukur dengan pendekatan kualitatif dengan beberapa parameter diantaranya performan tanaman yaitu tinggi tanaman, jumlah anakan, jumlah gabah per malai, dan produksi. Preferensi petani yang berkaitan dengan performan tananam (Tabel 7).

Tabel 7. Preferensi petani terhadap performance tanaman dari varietas Inpara 8, Inpari 30 dan Mekongga di Desa Jambu Ilir Kab.OKI, 2018

\begin{tabular}{lcccc}
\hline \multicolumn{5}{c}{ Preferensi Petani $(\%)$} \\
\hline Varietas & Sangat suka (SS) & Suka $(\mathrm{S})$ & Tidak Suka (TS) & Modus \\
\hline Inpara 8 & 100 & 0 & 0 & SS \\
Inpari 30 & 100 & 0 & 0 & SS \\
Mekongga & 20 & 80 & 0 & S \\
\hline
\end{tabular}

\section{PEMBAHASAN}

Tinggi tanaman Inpara 8 berbeda sangat nyata dengan Mekongga dan berbeda nyata dengan Inpari 30, sedangkan Inpari 30 tidak berbeda nyata dengan Mekongga. Inpara 8 merupakan tanaman tertinggi dari varietas lainnya yaitu 114,6 $\mathrm{cm}$ dan terendah $102,2 \mathrm{~cm}$ varietas Mekongga (Tabel 1). Tinggi tanaman tergolong rendah sampai sedang (102,2$114,6 \mathrm{~cm}$ ) sehingga tidak terjadi kerebahan. Pertumbuhan tinggi dan pendeknya tanaman padi berkaitan dengan ketahanan terhadap kerebahan dan menentukan tingkat keberhasilan panen. Semakin tinggi pertumbuhan tanaman maka memungkinkan akan terjadi kerebahan. Bervariasinya varietas yang dikaji disebabkan oleh faktor genetik dari masingmasing varietas dan faktor lingkungan dimana varietas tersebut ditanam. Dikemukakan oleh Waluyo dan Suparwoto (2016) bahwa tinggi tanaman merupakan salah satu karakter agronomi yang harus diperhatikan, karena jika tanaman terlalu tinggi maka tanaman akan mudah rebah akibat daya topang tanah yang lemah. Sehingga tanaman yang rebah akan mengalami permasalahan, bila terlambat panen bulir padi akan tumbuh maka kualitas padi akan turun. Dikemukakan oleh Asaad dan Warda (2011), tinggi tanaman merupakan salah satu kriteria seleksi pada 
tanaman padi, tetapi dengan pertumbuhan tanaman yang tinggi tidak menjamin tingkat produktivitasnya.

Inpara 8 dan Inpari 30 mempunyai anakan produktif lebih banyak dari Mekongga berturut-turut 16,2 dan 16,8 batang/rumpun (Tabel 2). Jumlah anakan tersebut tergolong sedang sampai tinggi, hal ini dapat dipengaruhi oleh kondisi lingkungan dimana varietas tersebut tumbuh diantaranya umur bibit dan juga faktor genetik dari varietas tersebut. Jumlah anakan produktif termasuk komponen hasil dimana semakin banyak anakan produktif maka hasil gabah akan semakin tinggi. Menurut Aryana et al., 2015), anakan produktif per rumpun merupakan penentu terhadap jumlah malai, sehingga anakan produktif berpengaruh terhadap tinggi rendahnya hasil gabah. Menurut Susilo et al., (2015), tanaman dengan kemampuan pembentukan jumlah anakan yang tinggi diprediksi akan memiliki produktivitas yang lebih tinggi dibandingkan dengan tanaman dengan jumlah anakan yang sedikit. Hal ini tentunya didukung oleh faktor pertumbuhan dan lingkungan yang memadai (Wibawa dan Rahman, 2016).

Panjang malai dari Inpara 8 dan Inpari 30 lebih panjang dari Mekongga berturut turut 26,2 dan 24, $9 \mathrm{~cm}$ (Tabel 3). Panjang malai berpengaruh terhadap hasil padi karena semakin panjang malai maka jumlah gabah per malai semakin banyak. Dikemukakan oleh Siregar et al., (1988) dalam Waluyo et al., (2015) bahwa panjang malai juga merupakan parameter pendukung untuk potensi hasil.

Jumlah gabah/malai dari Inpara 8 lebih banyak dari Mekongga dan Inpari 30 yaitu 157,3 butir/malai, berbeda sangat nyata dengan Mekongga dan berbeda tidak nyata dengan Inpari $30 . \quad$ Jumlah gabah/malai terrendah dimiliki oleh Mekongga yaitu 108,3 butir/malai (Tabel 4). Tinggi rendahnya persentase gabah isi per malai disebabkan oleh perbedaan tanggapan dan ketahanan tiap varietas terhadap kondisi lingkungan yang kurang menguntungkan, terutama pada fase reproduktif dan pemasakan. Dikemukakan oleh Endrizal dan Bobihoe (2007) dalam Aryana et al., (2015) bahwa jumlah gabah isi per malai berhubungan nyata dengan hasil tanaman tetapi sangat dipengaruhi oleh jumlah gabah hampa.

Produksi Inpara 8 dan Inpari 30 lebih tinggi dari Mekongga (4,1 ton GKP/ha), yaitu 5,3 dan 5,1 ton GKP/ha. Produksi yang dicapai oleh ke tiga varietas ini masih rendah bila dibandingkan deskripsi potensi hasilnya (Jamil, 2016). Potensi hasil dari Inpari 30 bisa mencapai 9,6 ton/ha, sedangkan Inpara 8 dan Mekongga rata-rata 6 ton/ha. Salah satu yang menyebabkan hasil rendah ini ialah jumlah anakan produktif per rumpun dari masing-masing varietas rata-rata 15,9 batang/rumpun. Selain itu jumlah gabah per malai berpengaruh terhadap produksi gabah (Helmi, 2015). Hasil gabah yang berbeda dikarenakan ada perbedaan sifat dari masing-masing varietas dan kondisi lingkungan tempat tumbuhnya (Ramli, 1993) dalam Waluyo dan Suparwoto (2016). Dikemukakan oleh Handoko et al., (2017) komponen hasil menentukan hasil tanaman padi seperti: jumlah malai per rumpun, jumlah gabah per malai, persentase gabah isi per malai dan berat 1000 biji. Selanjutnya Wahyudin et al. (2016), menyatakan bahwa pertumbuhan tanaman yang baik memungkinkan tanaman tersebut mampu memberikan hasil sesuai dengan potensi hasil yang dimiliki oleh masingmasing varietas. Inpara 8 dan Inpari 30 mempunyai jumlah gabah per malai dan jumlah gabah isi per malai lebih tinggi serta panjang malai lebih panjang daripada Mekongga sehingga hasil gabahnya per hektar lebih banyak.

Performan tanaman pada dasarnya petani suka terhadap varietas Inpara 8, Inpari 30 dan Mekongga karena tektur nasi pulen dan tahan rebah, tetapi Inpara 8 dan Inpari 30 sangat disukai $(100 \%)$ karena dilihat dari jumlah anakan, jumlah gabah/malai dan produksi lebih unggul dari pada Mekongga. 


\section{KESIMPULAN}

Dari uraian di atas dapat disimpulkan bahwa tinggi tanaman Inpari 30, dan Inpara 8 tergolong rendah sampai sedang sehingga varietas tersebut tidak ada yang rebah dapat beradaptasi baik di rawa lebak dengan produksi 5,1 dan 5,3 ton GKP/ha lebih tinggi dari Mekongga sebagai varietas pembanding dan sangat disukai para petani.

\section{UCAPAN TERIMA KASIH}

Ucapan terima kasih disampaikan kepada teman-teman teknisi Kebun Percobaan Kayuagung, penyuluh lapang dan semua pihak yang telah membantu kelancaran dalam pelaksanaan pengkajian ini.

\section{DAFTAR PUSTAKA}

Aryana, Muliarta IGP, Bambang BS, Ketut Sudharmawan AA, Allin S. 2015. Hasil dan komponen hasil galur harapan padi beras merah ampibi di lokasi dataran rendah Lombok Barat. Prosiding Seminar Nasional Inovasi Teknologi Padi Mendukung Pertanian Bioindustri. 19 Agustus 2014. Sukamandi: Balai Besar Penelitian Tanaman Padi.p 721-728

Asaad, Warda. 2011. Keragaan beberapa galur harapan padi sawah di Kabupaten Sidrap Sulawesi Selatan. Dalam : Bambang Suprihatno, Aan Andang Daradjat, Satoto, Baehaki, dan Sudir (Ed). Prosiding Seminar Ilmiah Hasil Penelitian Padi Nasional 2010. Balai Besar Penelitian Padi, Buku 1. Badan Litbang Pertanian Sukamandi. hlm: 77-86.

BP3K Tanjung Lubuk. 2014. Programa penyuluhan pertanian, perikanan dan kehutanan. Programa penyuluhan pertanian, perikanan dan kehutanan. BP3K Tanjung Lubuk.
BPS Prov Sumatera Selatan. 2016. Provinsi Sumatera Selatan Dalam Angka 2016. Badan Pusat Statistik Provinsi Sumatera Selatan. Palembang.

Helmi, Sembiring T. 2013. Penampilan produktivitas beberapa galur dan varietas jagung di Kabupaten Simalungun. Prosiding Seminar Nasional Buku 1 Balai Besar pengkajian dan Pengembangan Pertanian, Bogor.

Helmi. 2015. Peningkatan produktivitas padi lahan rawa melalui penggunaan varietas unggul padi rawa. Jurnal Pertanian Tropik. 2(2).

Handoko S, Farmanta Y, Adri. 2017. Peningkatan produktivitas padi sawah melalui introduksi varietas unggul baru di Kabupaten Tanjung Jabung Timur Jambi. Prosiding Seminar Nasional Pengkajian Teknologi Spesifik Lokasi Komoditas Tanaman Pangan, Bengkulu. 8 November 2016. hlm 96-100.

Jamil A, Satoto, Sasmita P, Baliadi Y, Guswara A, Suhama. 2016. Deskripsi Varietas Padi. Balai Besar Penelitian Tanaman Padi, Sukamandi.

Mustikawati DR. 2016. Keragaan beberapa varietas unggul padi di lahan rawa lebak Lampung Selatan. Buletin Inovasi Pertanian Spesifik Lokasi. 3(1):57-66

Soehendi R, Syahri. 2013. Kesesuaian Varietas Unggul Baru Padi di Sumatera Selatan. Dalam: Subaidi A, Sirnawati E, Yulianti A, Dewi YA, Istriningsih VW. Hanifah, Hutomo RS, Medionovianto D, Humaedah U, Dalmadi $(E d)$. Prosiding Seminar Nasional Inovasi Teknologi Pertanian Spesifik Lokasi. Balai Besar Pengkajian dan Pengembangan Teknologi Pertanian Medan, 6-7 Juni 2013. pp. 304-310. 
Suparwoto, Waluyo, Priatna S. 2017. Produksi dan usahatani padi varietas unggul baru di lahan rawa lebak Kabupaten Banyuasin Sumatera Selatan. Jurnal Penelitian Pertanian Terapan. 17(3):171-181

Suryana. 2016. Potensi dan Peluang Pengembangan Usahatani Terpadu Berbasis Kawasan Di Lahan Rawa. Jurnal Litbang Pertanian. 35(2):5768.

Susilo J, Ardian, Ariani E. 2015. Pengaruh jumlah bibit per lubang dan dosis pupuk N, P dan $\mathrm{K}$ terhadap pertumbuhan dan produksi padi sawah dengan metode SRI. JOP Faperta. 2(1): 1-15.

Waluyo, Hutapea Y, Suparwoto. 2015. Pengkajian varietas unggul baru padi (Inpari) di lahan sawah tadah hujan, Kabupaten Ogan Komering Ilir, Provinsi Sumatera Selatan. Prosiding Seminar Nasional 2014. Balai Besar Penelitian Tanaman Padi. Buku 2. Sukamandi, 19 Agustus 2014. hlm 631-642

Waluyo, Suparwoto. 2016. Peranan varietas padi unggul baru dalam meningkatkan produktivitas dan penghasilan petani lebak Kabupaten Ogan Ilir Sumatera Selatan. Prosiding Seminar Nasional Pertanian Terpadu dan Berkelanjutan Berbasis Sumber Daya dan Kearifan Lokal di Era Masyarakat Ekonomi ASEAN. Fakultas Pertanian Universitas Sriwijaya, 4 September 2016. hlm 198-208.

Wahyudin, A, Ruminta dan S.A.Nursarifah. 2016. Pertumbuhan dan hasil tanaman jagung toleran herbisida akibat pemberian berbagai dosis herbisida kalium glifosat. Jurnal Kultivasi. 15(2): 86-91.

Wibawa W, Rahman T. 2016. Budidaya padi aromatik pada lahan sawah irigasi. Dalam kumpulan makalah litkaji hasil penelitian pengembangan dan penerapan inovasi teknologi pertanian Bengkulu tahun 2015. Seminar diselenggarakan pada Desember 2015 di Bengkulu. hlm1-9. 